\title{
Investigating the Distance Education Process According to the Demographic Characteristics of the Notary and the Notary Employee
}

\author{
Gizem Yildiz \\ Gazi University, Turkey \\ ORCID: 0000-0002-3034-1047 \\ Ebru Kilic Cakmak \\ Gazi University, Turkey \\ ORCID: 0000-0002-3459-6290
}

\begin{abstract}
This study aims to reveal the investigating the distance education process according to the demographic characteristics for the staff of the notary and the notaries in Turkey. In this research survey method is used. The sample group consists of 317 notary and notary employees who responded voluntarily to the scale in the distance education platform. Demographic information form and distance education satisfaction scale were used as data collection tools. In the analysis, ANOVA, T-Test, Mann Whitney-U, Kruskal-Wallis and Pearson Correlation were performed in accordance with sub-problems. As a result of the analysis, it was concluded that the satisfaction of the participants was between the sub-factors and the general satisfaction between the middle and high level. All factors were found to have a high positive and significant relationship between general satisfaction and each other. The satisfaction of the participants showed a significant difference according to age, but did not show a significant difference according to gender, task type, duration of work in the profession, number of notary employees, educational level and participating in distance education previously. As a result of the research, planning the gamification, measurement and evaluation and certificate programs that the participants would provide more interaction on the platform were considered important. The contents of education were found to be effective on satisfaction.
\end{abstract}

Keywords: distance education, satisfaction, notary, notary employee, institution

\section{INTRODUCTION}

Distance education has a great impact on various fields around the world. The opportunities provided by distance education (Simonson, Zvacek, \& Smaldino, 2019) make it significant. Distance education has become an indispensable method for many institutions (Rumble, 2019). The personnel receive regular education for the success of the institutions and the provision of quality service. In order to prevent the loss of work tempo of the personnel and increase their efficiency, the institutions head towards the internet based distance educations (Yılmaz \& Düğenci, 2010). As the education is made possible in digital environments, most institutions offer educations by means of distance education. Banks, ministries, universities prefer distance education in personnel training. Banks provide interactive trainings and exams to their employees through distance education systems. Ministries provide in-service training to their personnel through distance education. In a similar way, in-service training of university personnel is provided in this way. Notaries Union of Turkey is among the institutions that support education through distance education with their personnel. 


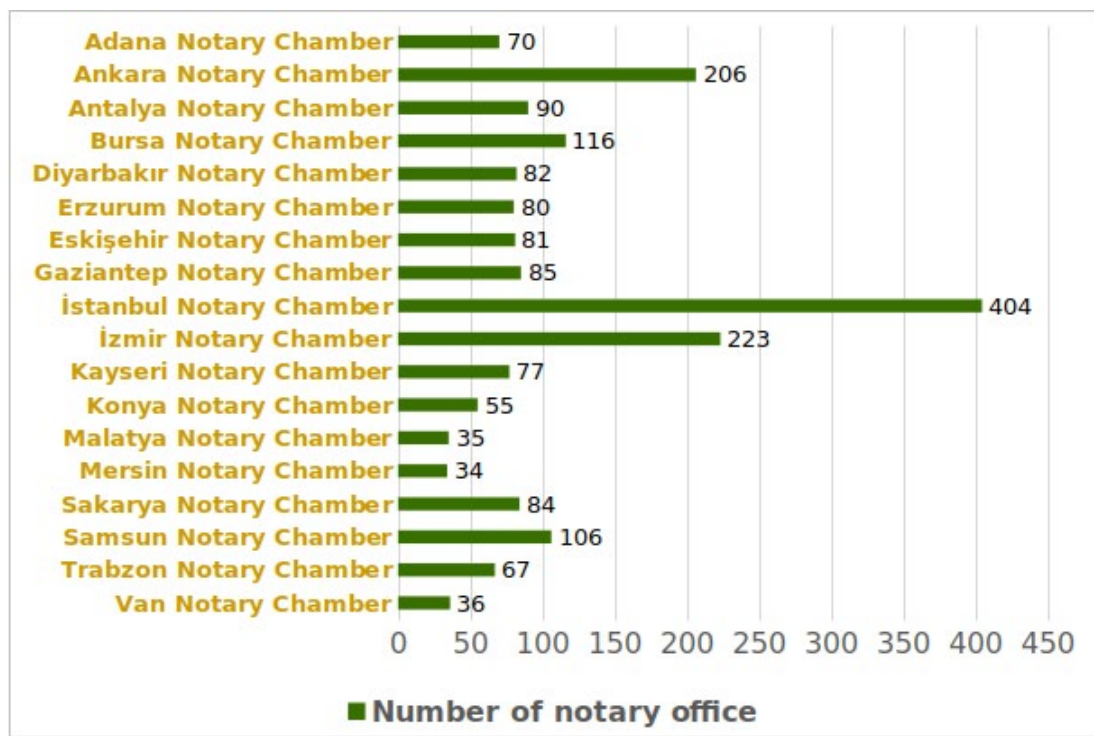

Figure 1. Notary connected to the notary chambers in Turkey

Notaries Union of Turkey is a professional organization with a legal personality as a public institution in Ankara, which was established to provide unity and cooperation among the colleagues of notary and notary employees and the development of the profession. One of the activities carried out within this organization is to provide trainings to notary employees. These trainings can be listed as procedure-based trainings given to notary employee for transactions and software trainings used in transactions. It is quite important to increase the service quality of the employees by learning the transactions quickly and to provide the service in the most accurate way with these trainings. As shown in Figure 1, there are 18 notary chambers in our country and there are 1931 notary chambers connected to these chambers. The total number of personnel working as a notary personnel is 9062 . Providing these trainings face to face for 9062 personnel is time consuming and costly.

The Distance Education Platform was launched to reduce the cost of trainings provided for notary operations and to prevent loss of time and labor. The platform aims to offer all the trainings from a single environment and to make the follow-up easier.

\section{DISTANCE EDUCATION AND SATISFACTION}

Güeçoğlu (2012) indicated that the importance of the strategy followed in distance education processes. It has been suggested that it is important to evaluate people with different dimensions from technical and psychological sufficiency, to increase their motivation, and to measure learning activities in terms of determining the strategy to be followed. It has also been suggested that it is important to have positive attitudes of individuals in order to achieve the desired success in the trainings (Yılmaz \& Düğenci, 2010). According to the literature, methods should be selected according to the profile of employees in distance education programs (Yılmaz \& Düğenci, 2010) so that satisfaction can be achieved.

Gülbahar (2012) stated that it is important to reveal the satisfaction of e-learning process participants towards the process and the level of satisfaction should be checked regularly. The studies emphasized the importance of satisfaction (Joo, Lim, \& Kim, 2011), suggesting that the satisfaction of the participants in distance education increases the success of the institutions (Baturay \& Yükseltürk, 2015; Şahin, 2009; Karataş \& Üstündağ, 2008; Eom, Wen, \& Ashill, 2006). Attitude of the trainer, content quality, content availability, flexibility of courses affect satisfaction (Sun, Tsei, Finger, Chen, \& Yeh, 2008). Learner satisfaction is affected by more than one factor in education and training environments (Simonson, Zvacek, \& Smaldino, 2019; Kantoğlu, Torkul, \& Altunışık, 2013). Some of these factors can be listed as content (Douglas \& Vyver, 2004), interaction between other students and trainers (Arbaugh \& Fich, 2007), time control, cost, learning, performance, experience (Adnan \& Boz-Yaman, 2017), material (Sahin \& Shelley, 2008) and success. It is 
indicated that instructional design and organization affected the learner satisfaction positively (Shea, Pickett, \& Pelz, 2003). Also, it is important that web-supported courses are accessible anytime and anywhere (Spector, Merrill, Elen, \& Bishop, 2014). The quality of the system, the content quality and instructor was emphasized for satisfaction (Simonson, Zvacek, \& Smaldino, 2019). It was also emphasized that trainer support, effectiveness and satisfaction are important in learner education. In this study, satisfaction, personal suitability, effectiveness, learning, evaluation of the program, technology, material, evaluation for distance education were examined in seven dimensions. The scale containing most of the dimensions obtained as a result of the literature review was used as data collection tool.

User registration of all personnel working in the Distance Education Platform has been established. Platform, video, document, training contents etc. were loaded and opened for use and distance education process was started. In addition, the procedures and the main trainings for the transactions performed by the notaries in software were conducted face to face according to the need. Face-to-face trainings are also supported by virtual classes through the platform. The distance education platform, which plays a role in the provision of important services, is deemed important in the effective design and implementation of the necessary interventions. In this study, it is aimed to determine the opinions of the personnel who have been using the distance education platform for one year and who have received the trainings about the distance education process. In this way, the process can be restructured by taking measures to make improvements and arrangements on the platform.

Sub-problems in the scope of the aim of the study are as follows.

1. What is the general satisfaction level of notary and notary employees?

2. Do notary's and notary employees's satisfaction with the distance education process differ significantly according to the following variables?

- gender,

- age group,

- task type,

- duration of work in the profession,

- to the number of notary office worked,

- educational level,

- previously participating in distance education.

3. Is there a relationship between the scale's factors which given below?

- General satisfaction

- Personal suitability

- Effectiveness

- Learning

- Evaluation of the program

- Technology

- Material

- Evaluation 
Table 1. Profile of the participants

\begin{tabular}{|c|c|c|c|}
\hline Size & Group & $\mathrm{N}$ & $\%$ \\
\hline \multirow[t]{3}{*}{ gender } & woman & 118 & 37.2 \\
\hline & male & 199 & 62.8 \\
\hline & total & 317 & 100.0 \\
\hline \multirow[t]{5}{*}{ age group } & $15-25$ years & 17 & 5.36 \\
\hline & $26-35$ years & 116 & 36.59 \\
\hline & $36-45$ years & 95 & 29.97 \\
\hline & 46 years and older & 89 & 28.08 \\
\hline & total & 317 & 100.0 \\
\hline \multirow{4}{*}{ task type } & notary & 48 & 15.14 \\
\hline & protonotary & 75 & 23.66 \\
\hline & clerk et al. & 194 & 61.20 \\
\hline & total & 317 & 100.0 \\
\hline duration of work & $0-5$ years & 110 & 26.50 \\
\hline \multirow[t]{3}{*}{ in the profession } & $6-15$ years & 123 & 38.80 \\
\hline & Over 15 years & 84 & 34.70 \\
\hline & Total & 317 & 100.0 \\
\hline the number of & 1 notary office & 171 & 53.94 \\
\hline \multirow[t]{2}{*}{ notary office worked } & more than 1 notary office & 146 & 46.06 \\
\hline & total & 317 & 100.0 \\
\hline \multirow[t]{4}{*}{ educational level } & primary and secondary school & 13 & 4.10 \\
\hline & high school & 120 & 37.85 \\
\hline & university & 184 & 58.04 \\
\hline & total & 317 & 100.0 \\
\hline \multirow[t]{3}{*}{ previously participating in distance education } & yes & 208 & 65.6 \\
\hline & no & 109 & 34.4 \\
\hline & total & 317 & 100.0 \\
\hline
\end{tabular}

\section{METHOD}

In this study, it was aimed to examine the distance education process according to the demographic characteristics of the participants. In this research survey method is used. Therefore, predictive and descriptive analysis was conducted. It has been studied predictively according to the general satisfaction and sub-dimensions of the notary employees and their demographic characteristics. Descriptively, the arithmetic mean, percent, and standard deviation values of the scores obtained from the scale were used to determine the satisfaction of the employees for the distance education process.

\section{Participants}

The participants of the study consisted of the notary and the notary employee in Turkey. 317 employee answered the scale voluntarily presented in the Distance Education Platform. The profile of the participants is given in Table 1.

As seen in Table 1, notary employees are mostly male employees $(\mathrm{N}=199)$. Notary public employees are mostly between the ages of 26-35 ( $N=116)$, their duties are clerk et al. $(\mathrm{N}=194)$ and their duration of work is between 6-15 years. It is seen that most of the noter employee work in one notary office $(\mathrm{N}=171)$. It is observed that most of the employees are university graduates $(\mathrm{N}=184)$ and have experienced the distance education process before $(\mathrm{N}=208)$.

\section{Designing and Delivering an Online Course}

The guides of the software were created in the form of short videos. In addition, animations of the content procedures and document of principles were created. Effective face-to-face training has also been provided, as this document consists of critical information that notaries need to know. The creation of videos has taken place as follows: 
- Distance education personnel received software training.

- Then the audio texts of the training videos were written and approval was received from the software experts.

- Images and animations have been created.

- The screen and sound recording of the software was taken.

- The completed videos were printed out and uploaded to the distance education platform.

- On the distance education platform, training videos for transactions are categorized and organized.

- The trainings were then assigned to users.

- As each training is assigned, users are notified and also announced.

If users have problems accessing to the system, they have contacted the relevant technical group. They were sent messages from the system about the issues that the users did not understand about the trainings. In addition to all these trainings, face-to-face trainings were also given to the personnel from time to time.

\section{Data Collection and Analysis}

The guides of the software were created in the form of short videos. In addition, animations of the content procedures and document of principles were created. Effective face-to-face training has also been provided, as this document consists of critical information that notaries need to know. The creation of videos has taken place as follows:

\section{The scale}

The scale adapted by Eygü and Karaman (2013) was used in the research. The scale was developed to examine learner satisfaction, students' ability to learn, and satisfaction with distance education. The scale type was a 5-point Likert. These are 1 (strongly disagree), 2 (disagree), 3 (undecided), 4 (agree), 5 (strongly agree). As a result of the factor analysis, the scale resulted in 8 factors as personal suitability, effectiveness, learning, evaluation of the program, technology, materials, evaluation and support services the scale consists of 34 items. In order to measure the reliability of the survey, the Cronbach's alpha coefficient was calculated and found to be 0.930 (Eygü \& Karaman, 2013).

The variances explained by the factors are as follows: Factor 1: 11.62; Factor 2: 9.94; Factor 3: 9.62; Factor 4: 9.48; Factor 5: 6.80; Factor 6: 6.41; Factor 7: 6.39; Factor 8: 5.26. Alpha coefficients according to factors are as follows: Personal suitability: 0.863; Effectiveness: 0.839; Learning: 0.753; Evaluation of the program: 0.775; Technology: 0.835; Material: 0.760; Evaluation: 0.706; Support services: 0.787. Also, some of the items related to the factors are as follows:

Factor 1- personal suitability: Distance education allows the student to learn at his own pace. /

Factor 2- effectiveness: When I had problems with the lessons, I was able to get the necessary support.

Factor 3- learning: Distance education is suitable for me because I have busy worklife.

Factor 4- evaluation of the program: Course contents were suitable for the purpose of the program.

Factor 5- technology: I have a social and friendly interaction with the trainer.

Factor 6- material: The topics in the course resources were consistent with each other.

Factor 7- evaluation: I easily accessed course contents via the system.

Factor 8- support services: The questions in the exam were consistent with the course contents. 
Table 2. Test of Homogeneity of Variances

\begin{tabular}{lcccc}
\hline & Levene Statistic & df1 & df2 & P \\
\hline Personal suitability-Gender & 5,431 & 1 & 315 &, 020 \\
Technology-Age group & 3,219 & 3 & 313 &, 023 \\
Evaluation-task type & 4,140 & 2 & 314 &, 017 \\
\hline
\end{tabular}

Table 3. Tests Used in the Study

\begin{tabular}{|c|c|c|c|c|c|c|c|c|}
\hline & $\begin{array}{c}\text { General } \\
\text { satisfaction }\end{array}$ & $\begin{array}{l}\text { Personal } \\
\text { suitability }\end{array}$ & Effectiveness & Learni & $\begin{array}{l}\text { Evaluation of } \\
\text { the program }\end{array}$ & Technology & Material & Evaluation \\
\hline gender & T-testi & $\begin{array}{c}\text { Mann } \\
\text { Whitney-U }\end{array}$ & T-testi & T-testi & $\begin{array}{c}\text { Mann } \\
\text { Whitney-U }\end{array}$ & T-testi & $\begin{array}{c}\text { Mann } \\
\text { Whitney-U }\end{array}$ & T-testi \\
\hline age group & ANOVA & ANOVA & ANOVA & ANOVA & $\begin{array}{l}\text { Kruskal- } \\
\text { Wallis }\end{array}$ & $\begin{array}{l}\text { Kruskal- } \\
\text { Wallis }\end{array}$ & $\begin{array}{l}\text { Kruskal- } \\
\text { Wallis }\end{array}$ & ANOVA \\
\hline task type & ANOVA & ANOVA & ANOVA & ANOVA & $\begin{array}{l}\text { Kruskal- } \\
\text { Wallis }\end{array}$ & ANOVA & $\begin{array}{l}\text { Kruskal- } \\
\text { Wallis }\end{array}$ & $\begin{array}{l}\text { Kruskal- } \\
\text { Wallis }\end{array}$ \\
\hline $\begin{array}{l}\text { duration of work in } \\
\text { the profession }\end{array}$ & ANOVA & ANOVA & ANOVA & ANOVA & $\begin{array}{l}\text { Kruskal- } \\
\text { Wallis }\end{array}$ & ANOVA & $\begin{array}{l}\text { Kruskal- } \\
\text { Wallis }\end{array}$ & ANOVA \\
\hline $\begin{array}{l}\text { the number of notary } \\
\text { office worked }\end{array}$ & T-testi & T-testi & T-testi & T-testi & $\begin{array}{c}\text { Mann } \\
\text { Whitney-U }\end{array}$ & T-testi & $\begin{array}{c}\text { Mann } \\
\text { Whitney-U }\end{array}$ & T-testi \\
\hline educational level & ANOVA & ANOVA & ANOVA & ANOVA & $\begin{array}{l}\text { Kruskal- } \\
\text { Wallis }\end{array}$ & ANOVA & $\begin{array}{l}\text { Kruskal- } \\
\text { Wallis }\end{array}$ & ANOVA \\
\hline $\begin{array}{l}\text { previously } \\
\text { participating in } \\
\text { distance education }\end{array}$ & T-testi & T-testi & T-testi & T-testi & $\begin{array}{c}\text { Mann } \\
\text { Whitney-U }\end{array}$ & T-testi & $\begin{array}{c}\text { Mann } \\
\text { Whitney-U }\end{array}$ & T-testi \\
\hline
\end{tabular}

A form was prepared to obtain demographic information with the scale. In the first part of the form, the questions prepared to determine the demographic characteristics of the participants were included. This section includes questions to provide information about the participants' gender, age, task type, number of notary personnel, duration of work in the profession, educational level, and previous participation in distance education. Scale items were included in the second part of the form. However, in this study, the support services factor was not included in the assessment because no exams were applied to the participants during the distance education process. The scale was presented on the Distance Education Platform for two months to test the satisfaction of the participants.

\section{Analysis of data}

The overall satisfaction of the participants was calculated with the average of the data obtained from the scale factors. General satisfaction is included in the data analysis. Statistical analysis of the data was carried out using the SPSS package program (Joseph, Hair, William, Black Barry \& Babin Rolph, 2014, s. 69). Firstly, normal distribution was examined before parametric tests were performed. It was checked whether the data was normally distributed or not. For this, skewness and kurtosis values were also reviewed. (Joseph, Hair, William, Black Barry \& Babin Rolph, 2014, s. 33-34). As a result, general satisfaction, personal suitability, effectiveness, learning, technology, evaluation sub-factors showed normal distribution. But evaluation of the program scores and materiel sub-factors scores did not show normal distribution. Secondly, the homogeneity test of the factor scores was made. The factors that were not significant in the homogeneity test results are given in Table 2.

As a result, it was determined that there was no homogeneous distribution between personal suitabilitygender, technology-age group and evaluation-task type. In line with the analysis made the tests used in the study are given in Table 3. The significance rate was taken as .05 in all tests.

\section{FINDINGS}

The analyzes made in line with the sub-problems are given respectively. 
Table 4. General Analysis of Satisfaction for Distance Education Process

\begin{tabular}{llccc}
\hline Factor & Min. & Max. & $\overline{\boldsymbol{X}}$ & SS \\
\hline General satisfaction & 1.00 & 5.00 & 3.76 & .75 \\
Personal suitability & 1.00 & 5.00 & 3.81 & .80 \\
Effectiveness & 1.00 & 5.00 & 3.54 & .87 \\
Learning & 1.00 & 5.00 & 3.83 & .86 \\
Evaluation of the program & 1.00 & 5.00 & 3.92 & .85 \\
Technology & 1.00 & 5.00 & 3.46 & .95 \\
Materiel & 1.00 & 5.00 & 3.81 & .82 \\
Evaluation & 1.00 & 5.00 & 3.92 & .85 \\
\hline
\end{tabular}

Table 5. Participants' Satisfaction of Distance Education Process by gender - T Test Results

\begin{tabular}{|c|c|c|c|c|c|c|c|}
\hline Factor & Gender & $\mathrm{N}$ & $\overline{\boldsymbol{X}}$ & SS & SD & $T$ & $\mathrm{P}$ \\
\hline \multirow[t]{2}{*}{ General satisfaction } & woman & 118 & 3,71 & .63 & .05 & \multirow{2}{*}{-.787} & \multirow{2}{*}{.432} \\
\hline & male & 199 & 3,78 & .81 & .05 & & \\
\hline \multirow[t]{2}{*}{ Effectiveness } & woman & 118 & 3,46 & .78 & .07 & \multirow{2}{*}{-1.271} & \multirow{2}{*}{.205} \\
\hline & male & 199 & 3,59 & .92 & .06 & & \\
\hline \multirow[t]{2}{*}{ Learning } & woman & 118 & 3,80 & .74 & .06 & \multirow{2}{*}{-.488} & \multirow{2}{*}{.626} \\
\hline & male & 199 & 3,85 & .93 & .06 & & \\
\hline \multirow[t]{2}{*}{ Technology } & woman & 118 & 3,35 & .90 & .08 & \multirow{2}{*}{-1.655} & \multirow{2}{*}{.099} \\
\hline & male & 199 & 3,53 & .97 & .06 & & \\
\hline \multirow[t]{2}{*}{ Evaluation } & woman & 118 & 3,84 & .77 & .07 & \multirow{2}{*}{-1.275} & \multirow{2}{*}{.203} \\
\hline & male & 199 & 3,97 & .90 & .06 & & \\
\hline
\end{tabular}

Note: ${ }^{*} p<.05$

In the first sub-problem of the study, analysis was conducted to determine the general satisfaction of the participants. As a result of the analysis, the average scores in terms of total and factor scores were examined and given in Table 4.

When Table 4 is analyzed, the average scores of the participants regarding the distance education process are; $\bar{X}=3.81$ for personal suitability, $\bar{X}=3.54$ for effectiveness, $\bar{X}=3.83$ for learning, $\bar{X}=3.92$ for evaluation of the program, $\bar{X}=3.46$ for technology, $\bar{X}=3.81$ for material, $\bar{X}=3.92$ for evaluation, $\bar{X}=3.76$ for general satisfaction. Based on these findings, it can be said that both the sub-factors and general satisfaction of the participants were between medium and high level.

Independent samples T-test and Mann-Whitney $\mathrm{U}$ test were used to determine whether the satisfaction scores of the participants, which is the second sub-problem of the study, for the distance education process showed a significant difference according to gender. Information on the analysis results is given in Tables $\mathbf{5}$ and 6.

As seen in Table 5, no statistically significant difference was found between the groups in the total satisfaction scores of participants regarding distance education process according to gender variable ( $t=-.787$, $p>.05)$. When the general average scores of satisfaction with distance education process were examined, it was seen that male participants $(\bar{X}=3.78)$ had close scores with female participants $(\bar{X}=3.71)$. Other factor scores were not significant. When the sub-dimensions were examined, in the effectiveness factor scores ( $t=-$ 1.27, $p>0.05)$, learning factor scores $(t=-0.48), p>0.05)$, technology factor scores $(t=-1.65, p>0.05)$ and evaluation factor scores $(t=-1.27, p>0.05)$ did not differ according to the gender variable.

As seen in Table 6, personal suitability factor scores ( $U=11124.5, p>0.05)$, evaluation of the program factor scores $(U=11209.5, p>0.05)$ and material factor scores $(U=11597.5, p>0.05)$ did not differ according to the gender variable. 
Table 6. Participants' Satisfaction of Distance Education Process by gender - Mann Whitney-U Test results

\begin{tabular}{|c|c|c|c|c|c|c|}
\hline Factor & Gender & $\mathrm{N}$ & Mean Rank & Sum of Ranks & $\mathrm{U}$ & $P$ \\
\hline \multirow[t]{2}{*}{ Personal suitability } & woman & 118 & 153.78 & 18145.50 & \multirow{2}{*}{11124.5} & \multirow{2}{*}{.433} \\
\hline & male & 199 & 162.10 & 32257.50 & & \\
\hline \multirow{2}{*}{$\begin{array}{l}\text { Evaluation of the } \\
\text { program }\end{array}$} & woman & 118 & 154.50 & 18230.50 & \multirow{2}{*}{11209.5} & \multirow{2}{*}{.491} \\
\hline & male & 199 & 161.67 & 32172.50 & & \\
\hline \multirow[t]{2}{*}{ Material } & woman & 118 & 157.78 & 18618.50 & \multirow{2}{*}{11597.5} & \multirow{2}{*}{.848} \\
\hline & male & 199 & 159.72 & 31784.50 & & \\
\hline
\end{tabular}

Note. ${ }^{*} p<.05$

Table 7. Participants' Satisfaction of Distance Education Process by Age Group - ANOVA Test Results

\begin{tabular}{|c|c|c|c|c|c|c|c|c|}
\hline Factor & Age group & $\mathrm{N}$ & $\bar{X}$ & SS & SD & $\mathrm{F}$ & $P$ & Significant differences \\
\hline \multirow[t]{4}{*}{ General satisfaction } & $15-25$ years & 17 & 3.67 & .50 & .12 & \multirow{4}{*}{4.65} & \multirow{4}{*}{$.003 *$} & \multirow{4}{*}{$\begin{array}{l}2-3 \\
3-4\end{array}$} \\
\hline & $26-35$ years & 116 & 3.66 & .87 & .08 & & & \\
\hline & $36-45$ years & 95 & 3.99 & .61 & .06 & & & \\
\hline & 46 years and older & 89 & 3.65 & .71 & .07 & & & \\
\hline \multirow[t]{4}{*}{ Personal suitability } & $15-25$ years & 17 & 3.75 & .51 & .12 & \multirow{4}{*}{3.58} & \multirow{4}{*}{$.014 *$} & \multirow{4}{*}{$2-3$} \\
\hline & $26-35$ years & 116 & 3.66 & .92 & .08 & & & \\
\hline & $36-45$ years & 95 & 4.02 & .70 & .07 & & & \\
\hline & 46 years and older & 89 & 3.79 & .74 & .07 & & & \\
\hline \multirow[t]{4}{*}{ Effectiveness } & $15-25$ years & 17 & 3.40 & .70 & .16 & \multirow{4}{*}{3.31} & \multirow{4}{*}{$.020^{*}$} & \multirow{4}{*}{$3-4$} \\
\hline & $26-35$ years & 116 & 3.50 & .96 & .08 & & & \\
\hline & $36-45$ years & 95 & 3.76 & .79 & .08 & & & \\
\hline & 46 years and older & 89 & 3.38 & .82 & .08 & & & \\
\hline \multirow[t]{4}{*}{ Learning } & $15-25$ years & 17 & 3.83 & .65 & .15 & \multirow{4}{*}{2.51} & \multirow{4}{*}{.058} & \\
\hline & 26-35 years & 116 & 3.78 & .99 & .09 & & & \\
\hline & $36-45$ years & 95 & 4.03 & .76 & .07 & & & \\
\hline & 46 years and older & 89 & 3.69 & .80 & .08 & & & \\
\hline \multirow[t]{4}{*}{ Evaluation } & $15-25$ years & 17 & 3.84 & .74 & .18 & \multirow{4}{*}{2.99} & \multirow{4}{*}{$.031^{*}$} & \multirow{4}{*}{$2-3$} \\
\hline & $26-35$ years & 116 & 3.80 & .98 & .09 & & & \\
\hline & $36-45$ years & 95 & 4.14 & .70 & .07 & & & \\
\hline & 46 years and older & 89 & 3.86 & .80 & .08 & & & \\
\hline
\end{tabular}

Note: ${ }^{*} \mathrm{p}<.05,1: 15-25$ years, $2: 26-35$ years, $3: 36-45$ years, $4: 46$ years and older

One-way ANOVA test and Kruskal-Wallis test were was applied to determine whether the satisfaction scores of the participants, which is the second sub-problem of the study, for the distance education process show a significant difference according to age group. Information on the results of the analysis is given in Tables 7 and 8.

When Table 7 is examined, general satisfaction $(F=4.65, p<0.05)$, personal suitability $(F=3.58, p<0.05)$, effectiveness $(F=3.31, p<0.05)$ and evaluation $(F=2.99, p<0.05)$ factor scores differed according to the age group variable. On the other hand, there was no significant difference in learning factor scores ( $F=2.51$, $p>0.05$ ) for distance education according to age group. When the general satisfaction dimension is examined, it can be said that the 36-45 age group has more positive thoughts about the process. Bonferroni test was performed in order to determine from which group the difference observed in the satisfaction scores of participants for distance education process according to age group. As a result of these test; general satisfaction of the participants in the age group of $26-35$ and $36-45$ and $36-45$ and 46 and over, the personal suitability of participants between the ages of $26-35$ and $36-45$, the effectiveness of participants between 36-45 and 46 years of age, the evaluations of participants in the 26-35 age group and the 36-45 age group differ significantly.

When Table 8 is examined, evaluation of the program factor scores $\left(X^{2}(s d=3, n=317)=12.03, p<0.05\right)$, material factor scores $\left(X^{2}(s d=3, n=317)=13.78, p<0.05\right)$ and technology factor scores $\left(X^{2}(s d=3, n=317)=\right.$ $14.19, p<0.05)$ differed according to the age group variable. 
Table 8. Participants' Satisfaction of Distance Education Process by Age Group - Kruskal-Wallis Test Results

\begin{tabular}{|c|c|c|c|c|c|c|c|}
\hline Factor & Gender & $\mathrm{N}$ & Mean Rank & SD & $x^{2}$ & $P$ & Significant differences \\
\hline Evaluation of the & $15-25$ years & 17 & 157.88 & \multirow{4}{*}{3} & \multirow{4}{*}{12.03} & \multirow{4}{*}{$.007^{*}$} & \multirow{4}{*}{$\begin{array}{l}2-3 \\
3-4\end{array}$} \\
\hline \multirow{3}{*}{ program } & $26-35$ years & 116 & 147.81 & & & & \\
\hline & $36-45$ years & 95 & 185.40 & & & & \\
\hline & 46 years and older & 89 & 145.62 & & & & \\
\hline \multirow[t]{4}{*}{ Material } & $15-25$ years & 17 & 157.88 & \multirow{4}{*}{3} & \multirow{4}{*}{13.78} & \multirow{4}{*}{$.003^{*}$} & \multirow{4}{*}{$\begin{array}{l}2-3 \\
3-4\end{array}$} \\
\hline & $26-35$ years & 116 & 147.81 & & & & \\
\hline & $36-45$ years & 95 & 185.40 & & & & \\
\hline & 46 years and older & 89 & 145.62 & & & & \\
\hline \multirow[t]{4}{*}{ Technology } & $15-25$ years & 17 & 122.06 & \multirow{4}{*}{3} & \multirow{4}{*}{14.19} & \multirow{4}{*}{$.003^{*}$} & \multirow{4}{*}{$3-4$} \\
\hline & $26-35$ years & 116 & 157.78 & & & & \\
\hline & $36-45$ years & 95 & 184.46 & & & & \\
\hline & 46 years and older & 89 & 140.47 & & & & \\
\hline
\end{tabular}

Note: ${ }^{*} p<.05$

Table 9. Participants' Satisfaction of Distance Education Process by Type of Task-ANOVA Test Results

\begin{tabular}{|c|c|c|c|c|c|c|c|}
\hline Factor & Task type & $\mathrm{N}$ & $\overline{\boldsymbol{X}}$ & SS & SD & $\mathrm{F}$ & $P$ \\
\hline General & notary & 48 & 3.71 & .60 & .08 & & \\
\hline \multirow[t]{2}{*}{ satisfaction } & protonotary & 75 & 3.73 & .86 & .09 & .220 & .803 \\
\hline & clerk et al. & 194 & 3.78 & .74 & .05 & & \\
\hline Personal & notary & 48 & 3.83 & .67 & .09 & & \\
\hline \multirow[t]{2}{*}{ suitability } & protonotary & 75 & 3.77 & .85 & .09 & .094 & .910 \\
\hline & clerk et al. & 194 & 3.82 & .82 & .05 & & \\
\hline \multirow[t]{3}{*}{ Effectiveness } & notary & 48 & 3.45 & .75 & .10 & & \\
\hline & protonotary & 75 & 3.49 & .98 & .11 & .654 & .520 \\
\hline & clerk et al. & 194 & 3.59 & .85 & .06 & & \\
\hline \multirow[t]{3}{*}{ Learning } & notary & 48 & 3.76 & .69 & .10 & & \\
\hline & protonotary & 75 & 3.83 & .96 & .11 & .200 & .819 \\
\hline & clerk et al. & 194 & 3.85 & .85 & .06 & & \\
\hline \multirow[t]{3}{*}{ Technology } & notary & 48 & 3.29 & .88 & .12 & & \\
\hline & protonotary & 75 & 3.52 & 1.02 & .11 & .931 & .395 \\
\hline & clerk et al. & 194 & 3.48 & .93 & .06 & & \\
\hline
\end{tabular}

Note: ${ }^{*} p<.05$

Mann Whitney-U test was performed in order to determine from which group the difference observed in the satisfaction scores of participants for distance education process according to age group. As a result of these test; evaluation of the program of participants in the age group of 26-35 years and 36-45 years and 36-45 years and 46 years and older, material of participants in the age group of 26-35 years and 36-45 years and 36- 45 years and 46 years and older, technology for participants of 36-45 age group and 46 age group differ significantly.

One-way ANOVA test and Kruskal-Wallis test were used to determine whether the satisfaction scores of participants, which is the second sub-problem of the study, for the distance education process differ significantly according to the type of task. Information on the results of the analysis is given in Tables $\mathbf{9}$ and 10.

When Table 9 is examined, general satisfaction $(F=0.22, p>0.05)$, personal suitability $(F=0.09, p>0.05)$, effectiveness $(F=0.65, p>0.05)$, learning $(F=.20, p>0.05)$ and technology $(F=.93, p>0.05)$ factor scores did not differ according to the task type variable.

When Table 10 is examined, evaluation of the program factor scores $\left(X^{2}(s d=2, n=317)=1.43, p>0.05\right)$, material factor scores $\left(X^{2}(s d=2, n=317)=.74, p>0.05\right)$ and evaluation factor scores $\left(X^{2}(s d=2, n=317)=2.20\right.$, $p>0.05)$ did not differ according to the task type variable. 
Table 10. Participants' Satisfaction of Distance Education Process by Type of Task- Kruskal-Wallis Test Results

\begin{tabular}{llccccc}
\hline Factor & Task type & $\mathrm{N}$ & Mean Rank & SD & $\mathrm{X}^{2}$ & $\mathrm{P}$ \\
\hline Evaluation of the & notary & 48 & 146.99 & & & \\
program & protonotary & 75 & 166.87 & 2 & 1.43 & .487 \\
& clerk et al. & 194 & 158.93 & & & \\
\hline Material & notary & 48 & 151.59 & & .74 & .690 \\
& Proton otary & 75 & 155.40 & 2 & & \\
\hline Evaluation & clerk et al. & 194 & 162.22 & & & .330 \\
& notary & 48 & 142,25 & & 2.20 & \\
\hline
\end{tabular}

Note: ${ }^{*} p<.05$

Table 11. Participants' Satisfaction of Distance Education Process by Duration of Work in the ProfessionANOVA Test Results

\begin{tabular}{|c|c|c|c|c|c|c|c|}
\hline Factor & $\begin{array}{l}\text { Duration of Work in the } \\
\text { Profession }\end{array}$ & $\mathrm{N}$ & $\bar{X}$ & SS & SD & $\mathrm{F}$ & $P$ \\
\hline \multirow[t]{3}{*}{ General satisfaction } & $0-5$ years & 110 & 3.69 & .68 & .06 & & \\
\hline & $6-15$ years & 123 & 3.81 & .79 & .07 & .70 & .496 \\
\hline & Over 15 years & 84 & 3.76 & .77 & .08 & & \\
\hline \multirow[t]{3}{*}{ Personal suitability } & $0-5$ years & 110 & 3.75 & .78 & .07 & & \\
\hline & $6-15$ years & 123 & 3.82 & .86 & .07 & .55 & .573 \\
\hline & Over 15 years & 84 & 3.87 & .74 & .08 & & \\
\hline \multirow[t]{3}{*}{ Effectiveness } & $0-5$ years & 110 & 3.51 & .84 & .08 & & \\
\hline & $6-15$ years & 123 & 3.58 & .91 & .08 & .20 & .816 \\
\hline & Over 15 years & 84 & 3.54 & .86 & .09 & & \\
\hline \multirow[t]{3}{*}{ Learning } & $0-5$ years & 110 & 3.79 & .75 & .07 & & \\
\hline & $6-15$ years & 123 & 3.89 & .94 & .08 & .40 & .671 \\
\hline & Over 15 years & 84 & 3.80 & .89 & .09 & & \\
\hline \multirow[t]{3}{*}{ Technology } & $0-5$ years & 110 & 3.35 & .92 & .08 & & \\
\hline & $6-15$ years & 123 & 3.59 & .93 & .08 & 2.01 & .135 \\
\hline & Over 15 years & 84 & 3.42 & .99 & .10 & & \\
\hline \multirow[t]{3}{*}{ Evaluation } & $0-5$ years & 110 & 3.86 & .81 & .07 & & \\
\hline & $6-15$ years & 123 & 3.97 & .87 & .07 & .51 & .596 \\
\hline & Over 15 years & 84 & 3.92 & .88 & .09 & & \\
\hline
\end{tabular}

Note: ${ }^{*} p<.05$

One-way ANOVA test and Kruskal-Wallis test were applied to determine whether the satisfaction scores of the participants second sub-problem, which is related to distance education, according to the duration of work in the profession. Information on the results of the analysis is given in Tables $\mathbf{1 1}$ and $\mathbf{1 2}$.

As shown in Table 11, general satisfaction $(F=0.70, p>0.05)$, personal suitability $(F=0.55, p>0.05)$, effectiveness ( $F=0.20, p>0.05)$, learning $(F=0.40, p>0.05)$ technology $(F=2.01, p>0.05)$ and evaluation $(F=0.51$, $p>0.05$ ) factor scores did not differ according to the duration of work in the profession variable.

As shown in Table 12, evaluation of the program factor scores $\left(X^{2}(s d=2, n=317)=.7, p>0.05\right)$ and material factor scores $\left(X^{2}(s d=2, n=317)=1.17, p>0.05\right)$ did not differ according to the duration of work in the profession variable. 
Table 12. Participants' Satisfaction of Distance Education Process by Duration of Work in the ProfessionKruskal-Wallis Test Results

\begin{tabular}{llccccc}
\hline Factor & Duration of Work in the Profession & $\mathrm{N}$ & Mean Rank & SD & $X^{2}$ & $\mathrm{P}$ \\
\hline Evaluation of the & $0-5$ years & 110 & 153.46 & & & .70 \\
program & $6-15$ years & 123 & 160.69 & 2 & & .704 \\
& Over 15 years & 84 & 163.79 & & & \\
\hline Material & $0-5$ years & 110 & 152.54 & & 1.17 & .557 \\
& $6-15$ years & 123 & 164.90 & 2 & & \\
\hline
\end{tabular}

Note: ${ }^{*} \mathrm{p}<.05$

Table 13. Participants' Satisfaction of Distance Education Process by Number Of Notary Office Worked $-T$ Test Results

\begin{tabular}{|c|c|c|c|c|c|c|c|}
\hline Factor & Number of notary office worked & $\mathrm{N}$ & $\overline{\bar{X}}$ & SS & SD & $T$ & $P$ \\
\hline \multirow[t]{2}{*}{ General satisfaction } & 1 notary office & 171 & 3.73 & .69 & .05 & \multirow{2}{*}{-.732} & \multirow{2}{*}{.115} \\
\hline & more than 1 notary office & 146 & 3.79 & .81 & .06 & & \\
\hline \multirow[t]{2}{*}{ Personal suitability } & 1 notary office & 171 & 3.76 & .77 & .05 & \multirow{2}{*}{-1.117} & \multirow{2}{*}{.494} \\
\hline & more than 1 notary office & 146 & 3.86 & .83 & .06 & & \\
\hline \multirow[t]{2}{*}{ Effectiveness } & 1 notary office & 171 & 3.51 & .85 & .06 & \multirow{2}{*}{-.636} & \multirow{2}{*}{.619} \\
\hline & more than 1 notary office & 146 & 3.58 & .90 & .07 & & \\
\hline \multirow[t]{2}{*}{ Learning } & 1 notary office & 171 & 3.83 & .79 & .06 & \multirow{2}{*}{-.012} & \multirow{2}{*}{.129} \\
\hline & more than 1 notary office & 146 & 3.83 & .94 & .07 & & \\
\hline \multirow[t]{2}{*}{ Technology } & 1 notary office & 171 & 3.40 & .91 & .06 & \multirow{2}{*}{-1.263} & \multirow{2}{*}{.254} \\
\hline & more than 1 notary office & 146 & 3.54 & .99 & .08 & & \\
\hline \multirow[t]{2}{*}{ Evaluation } & 1 notary office & 171 & 3.88 & .80 & .06 & \multirow{2}{*}{-.839} & \multirow{2}{*}{.358} \\
\hline & more than 1 notary office & 146 & 3.96 & .91 & .07 & & \\
\hline
\end{tabular}

Note: ${ }^{*} \mathrm{p}<.05$

Table 14. Participants' Satisfaction of Distance Education Process by Number Of Notary Office Worked - Mann Whitney-U Test Results

\begin{tabular}{|c|c|c|c|c|c|c|}
\hline Factor & $\begin{array}{l}\text { Number of notary office } \\
\text { worked }\end{array}$ & $\mathrm{N}$ & Mean Rank & Sum of Ranks & $U$ & $P$ \\
\hline \multirow{2}{*}{$\begin{array}{l}\text { Evaluation of the } \\
\text { program }\end{array}$} & 1 notary office & 171 & 155.52 & 26593.50 & \multirow{2}{*}{11887.5} & \multirow{2}{*}{.454} \\
\hline & more than 1 notary office & 146 & 163.08 & 23809.50 & & \\
\hline \multirow[t]{2}{*}{ Material } & 1 notary office & 171 & 158.51 & 27104.50 & \multirow{2}{*}{12398.5} & \multirow{2}{*}{.913} \\
\hline & more than 1 notary office & 146 & 159.58 & 23298.50 & & \\
\hline
\end{tabular}

Note: ${ }^{*} p<.05$

Independent samples T-test and Mann-Whitney $\mathrm{U}$ test were applied to determine whether the second subproblem of the research, satisfaction scores of participants for distance education process showed a significant difference according to the number of notary office worked. Information on the analysis results is given in Tables 13 and 14.

When Table 13 is analyzed, general satisfaction scores ( $t=-, 732, p>0.05)$, personal suitability factor scores ( $t=-$ $1,117, p>0.05)$, effectiveness factor scores $(t=-.636, p>0.05)$, learning factor scores $(t=-, 012, p>0.05)$, technology factor scores $(t=-1,263, p>0.05)$ and evaluation factor scores $(t=-, 839, p>0.05)$ did not differ according to the number of notary office worked variable. When the general satisfaction dimension is examined, it can be said that those who work in more than 1 notary personnel have more positive thoughts about the process.

When Table 14 is analyzed, evaluation of the program factor scores $(U=11887.5, p>0.05)$, material factor scores $(U=12398.5, p>0.05)$ did not differ according to the number of notary office worked variable.

One-way ANOVA test and Kruskal-Wallis test were used to determine whether the satisfaction scores of the participants, which is the second sub-problem of the study, for the distance education process showed a 
Table 15. Participants' Satisfaction of Distance Education Process by Education Level -ANOVA Test Results

\begin{tabular}{|c|c|c|c|c|c|c|c|}
\hline Factor & Education level & $\mathrm{N}$ & $\overline{\boldsymbol{X}}$ & SS & SD & $T$ & $P$ \\
\hline \multirow[t]{3}{*}{ General satisfaction } & primary and secondary school & 13 & 3.89 & .99 & .27 & & \\
\hline & high school & 120 & 3.78 & .78 & .07 & .41 & 659 \\
\hline & university & 184 & 3.73 & .71 & .05 & & \\
\hline \multirow[t]{3}{*}{ Personal suitability } & primary and secondary school & 13 & 4.04 & .74 & .2 & & \\
\hline & high school & 120 & 3.85 & .84 & .07 & .98 & .373 \\
\hline & university & 184 & 3.76 & .78 & .05 & & \\
\hline \multirow[t]{3}{*}{ Effectiveness } & primary and secondary school & 13 & 3.43 & 1.04 & .28 & & \\
\hline & high school & 120 & 3.58 & .93 & .08 & .23 & .792 \\
\hline & university & 184 & 3.53 & .81 & .06 & & \\
\hline \multirow[t]{3}{*}{ Learning } & primary and secondary school & 13 & 4.01 & 1.21 & .33 & & \\
\hline & high school & 120 & 3.85 & .86 & .07 & .38 & .681 \\
\hline & university & 184 & 3.81 & .84 & .06 & & \\
\hline \multirow[t]{3}{*}{ Technology } & primary and secondary school & 13 & 3.71 & 1.12 & .31 & & \\
\hline & high school & 120 & 3.51 & .93 & .08 & .88 & .413 \\
\hline & university & 184 & 3.41 & .95 & .07 & & \\
\hline \multirow[t]{3}{*}{ Evaluation } & primary and secondary school & 13 & 4.00 & 1.23 & .34 & & \\
\hline & high school & 120 & 3.92 & .89 & .08 & .05 & .949 \\
\hline & university & 184 & 3.92 & .80 & .05 & & \\
\hline
\end{tabular}

Note: ${ }^{*} p<.05$

Table 16. Participants' Satisfaction of Distance Education Process by Education Level - Kruskal-Wallis Test Results

\begin{tabular}{|c|c|c|c|c|c|c|}
\hline Factor & Education level & $\mathrm{N}$ & Mean Rank & SD & $\mathrm{X}^{2}$ & $\mathrm{P}$ \\
\hline Evaluation of the & primary and secondary school & 13 & 191.23 & & & \\
\hline \multirow[t]{2}{*}{ program } & high school & 120 & 164.70 & 2 & 2.98 & .224 \\
\hline & university & 184 & 153.00 & & & \\
\hline \multirow[t]{3}{*}{ Material } & primary and secondary school & 13 & 183.54 & & & \\
\hline & high school & 120 & 161.08 & 2 & 1.33 & .513 \\
\hline & university & 184 & 155.91 & & & \\
\hline
\end{tabular}

Note: ${ }^{*} p<.05$

significant difference according to the educational level. Information on the results of the analysis is given in Tables 15 and 16.

As shown in Table 15, general satisfaction scores $(F=.41, p>0.05)$, personal suitability factor scores $(F=0.98$, $p>0.05)$, effectiveness factor scores $(F=0.23, p>0.05)$, learning factor scores $(F=.38, p>0.05)$, technology factor scores $(F=.88, p>0.05)$ and evaluation factor scores $(F=.05, p>0.05)$ did not differ according to the education level variable.

As shown in Table 16, evaluation of the program factor scores $\left(X^{2}(s d=2, n=317)=2.98, p>0.05\right)$ and material factor scores $\left(X^{2}(s d=2, n=317)=1.33, p>0.05\right)$ did not differ according to the education level variable.

Independent samples T-test and Mann-Whitney $U$ test were used to determine whether the satisfaction scores of participants, which is the fourth sub-problem of the study, regarding the distance education process showed a significant difference compared to the status of participation in distance education. Information on the results of the analysis is given in Tables $\mathbf{1 7}$ and $\mathbf{1 8 .}$

When Table 17 is analyzed, general satisfaction scores $(t=0.81, p>0.05)$, personal suitability factor scores $(t=0.38, p>0.05)$, effectiveness factor scores $(t=1.25, p>0.05)$, learning factor scores $(t=1.05, p>0.05)$ and evaluation factor scores $(t=-0.33, p>0.05)$ did not differ according to whether or not he / she has participated in distance education before. The technology factor scores of the personnel who participated in distance education were higher than those who did not participate and the difference between the groups was statistically significant $(t=2.03, p<0.05)$. The questions in the technology factor are as follows: (1) I have a 
Table 17. Participants' Satisfaction of Distance Education Process by Previous Participation in Distance Education -T Test Results

\begin{tabular}{|c|c|c|c|c|c|c|c|}
\hline Factor & $\begin{array}{l}\text { Previous participation in } \\
\text { distance education }\end{array}$ & $\mathrm{N}$ & $\bar{X}$ & SS & SD & $T$ & $P$ \\
\hline \multirow[t]{2}{*}{ General satisfaction } & yes & 208 & 3.7861 & .78741 & .05460 & \multirow{2}{*}{.818} & \multirow{2}{*}{.414} \\
\hline & no & 109 & 3.7133 & .67956 & .06509 & & \\
\hline \multirow[t]{2}{*}{ Personal suitability } & yes & 208 & 3.8248 & .82546 & .05724 & \multirow{2}{*}{.386} & \multirow{2}{*}{.700} \\
\hline & no & 109 & 3.7880 & .77062 & .07381 & & \\
\hline \multirow[t]{2}{*}{ Effectiveness } & yes & 208 & 3.5913 & .89233 & .06187 & \multirow{2}{*}{1.250} & \multirow{2}{*}{.212} \\
\hline & no & 109 & 3.4624 & .83342 & .07983 & & \\
\hline \multirow[t]{2}{*}{ Learning } & yes & 208 & 3.8748 & .90948 & .06306 & \multirow{2}{*}{1.050} & \multirow{2}{*}{.294} \\
\hline & no & 109 & 3.7670 & .78198 & .07490 & & \\
\hline \multirow[t]{2}{*}{ Technology } & yes & 208 & 3.5465 & .95130 & .06596 & \multirow{2}{*}{2.036} & \multirow{2}{*}{$.043^{*}$} \\
\hline & no & 109 & 3.3180 & .94432 & .09045 & & \\
\hline \multirow[t]{2}{*}{ Evaluation } & yes & 208 & 3.9359 & .89079 & .06177 & \multirow{2}{*}{-.333} & \multirow{2}{*}{.740} \\
\hline & no & 109 & 3.9021 & .79259 & .07592 & & \\
\hline
\end{tabular}

Note: ${ }^{*} p<.05$

Table 18. Participants' Satisfaction of Distance Education Process by Previous Participation in Distance Education - Mann Whitney-U Test Results

\begin{tabular}{|c|c|c|c|c|c|c|}
\hline Factor & $\begin{array}{l}\text { Previous participation in } \\
\text { distance education }\end{array}$ & $\mathrm{N}$ & Mean Rank & Sum of Ranks & $U$ & $P$ \\
\hline \multirow{2}{*}{$\begin{array}{l}\text { Evaluation of the } \\
\text { program }\end{array}$} & yes & 208 & 162.08 & 33712.00 & \multirow{2}{*}{10696.000} & \multirow{2}{*}{.399} \\
\hline & no & 109 & 153.13 & 16691.00 & & \\
\hline \multirow[t]{2}{*}{ Material } & yes & 208 & 161.93 & 33682.00 & \multirow{2}{*}{10726.000} & \multirow{2}{*}{.407} \\
\hline & no & 109 & 153.40 & 16721.00 & & \\
\hline
\end{tabular}

Note: ${ }^{*} p<.05$

Table 19. Relationship Between the Scale's Factors

\begin{tabular}{|c|c|c|c|c|c|c|c|c|}
\hline & $\begin{array}{c}\text { General } \\
\text { satisfactior }\end{array}$ & $\begin{array}{l}\text { Personal } \\
\text { suitability }\end{array}$ & Effectivenes & Learning & $\begin{array}{l}\text { Evaluation } \\
\text { of the } \\
\text { program }\end{array}$ & Technology & Materiel & Evaluation \\
\hline General satisfaction & 1 & $.902^{* *}$ & $.862^{* *}$ & $.864^{* *}$ & $.928 * *$ & $.786 * *$ & $.924^{* *}$ & $.854^{* *}$ \\
\hline Personal suitability & & 1 & $.741^{* *}$ & $.791 * *$ & $.852 * *$ & $.586 * *$ & $.821 * *$ & $.752 * *$ \\
\hline Effectiveness & & & 1 & $.654 * *$ & $.747^{* *}$ & $.698 * *$ & $.768 * *$ & $.660 * *$ \\
\hline Learning & & & & 1 & $.804^{* *}$ & $.586 * *$ & $.737 * *$ & $.721 * *$ \\
\hline Evaluation of the program & & & & & 1 & $.626 * *$ & $.884 * *$ & $.780 * *$ \\
\hline Technology & & & & & & 1 & $.696 * *$ & $.565^{* *}$ \\
\hline Materiel & & & & & & & 1 & $.757^{* *}$ \\
\hline Evaluation & & & & & & & & 1 \\
\hline
\end{tabular}

**. Correlation is significant at the 0.01 level (2-tailed)

social and friendly interaction with the education manager in distance education (2) I have a social and friendly interaction with other participants in distance education. (3) In distance education, I can be like myself in my communication with the education manager and show what kind of participant I really am. These items include situations that require interaction in the distance education platform. The experience of participants who have previously had distance education experience may have supported this finding.

When Table 18 is analyzed, evaluation of the program factor scores $(U=10696, p>0.05)$ and material factor scores $(U=10726, p>0.05)$ did not differ according to whether or not he / she has participated in distance education before.

The data related to the Pearson correlation between the seven factors in the scale, which is the third subproblem of the study, is given in Table 19. 
Table 20. Findings of the Study

Problem Result

Do the general satisfaction of the participants Satisfaction of the participants is between medium and high levels of differ? both sub-factors and general satisfaction.

Do the participants' satisfaction with the distance education process differ significantly according to the following variables?

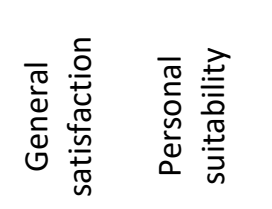

\begin{tabular}{|c|c|}
\hline 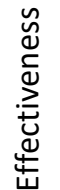 & 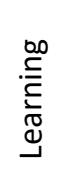 \\
\hline
\end{tabular}

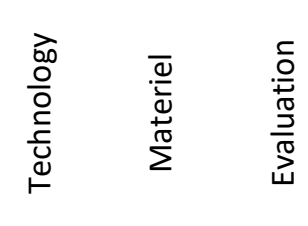

\begin{tabular}{|c|c|c|c|c|c|c|c|c|}
\hline - gender & $x$ & $x$ & $x$ & $x$ & $x$ & $x$ & $x$ & $x$ \\
\hline - age group & $\sqrt{ }$ & $\sqrt{ }$ & V & $x$ & $\mathrm{~V}$ & $\mathrm{~V}$ & $\sqrt{ }$ & $\sqrt{ }$ \\
\hline - task type & $x$ & $x$ & $x$ & $x$ & $x$ & $x$ & $x$ & $\mathrm{x}$ \\
\hline - duration of work in the profession & $x$ & $x$ & $x$ & $x$ & $x$ & $x$ & $x$ & $x$ \\
\hline - the number of notary office worked & $x$ & $x$ & $x$ & $x$ & $x$ & $x$ & $x$ & $\mathrm{x}$ \\
\hline • educational level & $x$ & $x$ & $x$ & $x$ & $x$ & $x$ & $x$ & $\mathrm{x}$ \\
\hline - previously participating in distance education & $x$ & $x$ & $\mathrm{x}$ & $x$ & $x$ & $\mathrm{~V}$ & $x$ & $\mathrm{x}$ \\
\hline
\end{tabular}

Is there a relationship between the scale's factors?

There is a high positive and significant relationship between overall

$\mathrm{X}$ : not significant; $\mathrm{V}$ : significant satisfaction of all factors.

When Table 19 is examined, it is seen that there is a high positive and significant relationship between all factors and general satisfaction. When the factors were examined one by one;

- there was a high positive and significant relationship between general satisfaction material, $r=0.924$, $\mathrm{p}<.01$.

- there is a high positive and significant relationship between personal suitability and program evaluation, $r=0.852, p<.01$.

- there is a high positive and significant relationship between efficacy and material, $r=0.768, p<.01$.

- a high positive and significant relationship between learning and personal suitability, $r=0.791, p<.01$.

- there is a high positive and significant relationship between the evaluation of the program and the material, $r=0.884, p<.01$.

- a high positive and significant relationship between technology and effectiveness, $r=0.698, p<.01$.

- There is a high positive and significant relationship between evaluation and program evaluation, $r=0.780$, $p<.01$.

All findings of the study are summarized in Table 20.

\section{DISCUSSIONS AND CONCLUSION}

Distance education plays a major role in the development of human resources in institutions (Martin, Massy, $\&$ Clarke, 2003). Trainings are usually conducted to ensure maximum profitability for organizations. Platforms offered to users through distance education prevent cost and loss of time (Macpherson, Homan, \& Wilkinson, 2005; Mwanza \& Engeström, 2005; Yılmaz \& Düğenci, 2010). In this case, distance education platforms are offered to users as a solution instead of a tool (Adams, 2004; Alonso, López, Manrique, \& Viñes, 2005). Justice (2005) also described the primary benefit of distance education environments as supporting education and development. The development of technology and communication, employees working in institutions must constantly improve their competencies (Yılmaz \& Düğenci, 2010). On the other hand, distance education is indispensable for large-scale organizations, especially for institutions that serve the whole country or the world (Yılmaz \& Düğenci, 2010). It is also quite important for institutions whose legislation or content is 
frequently changed, as e-content through distance education can be easily updated. In addition, distance education provides an environment for the personnel to gain new talent and skills (Toker Gökçe, 2008). In this study, the advantages provided by the distance education platform to the personnel are effective in the high level of satisfaction of the personnel for the distance education process. In the study of Öztürk, Kara, Özkeskin, and Uça Güneş (2017), it was found that learners were highly satisfied with the system and the content provided in the system. Gürpınar, Zayim, Başarıcı, Gündüz, Asar, and Oğuz (2009) stated that the satisfaction of the learners towards the e-learning environment was high in the study where they examined the learner satisfaction towards the e-learning environment they developed for cardiology students. In line with the data obtained within the scope of the research, it was considered important to increase the functionality of the platform by defining gamification, measurement and evaluation and certificate programs in the distance education platform used in the institution. In his book, he emphasizes the system that includes activities where different groups and organizations can take responsibility and collaborate on distance education platforms (Rumble, 2019).

In this study, it was concluded that there was a high level of positive and significant relationship between general satisfaction, personal suitability and program evaluation dimensions compared to other dimensions. From this point of view, the satisfaction of distance education users is shaped according to the content and functionality of the education materials in the process.

It was inferred that the satisfaction of the personnel did not show a significant difference according to gender. According to the learning management system used in Anadolu University and the content presented in the system, learner satisfaction was analyzed according to various demographic characteristics. At the end of the study, learner satisfaction did not differ significantly by gender (Öztürk, Kara, Özkeskin, \& Uça Güneş, 2017). In Adnan and Boz Yaman's (2017) study, the satisfaction of learners towards e-learning did not differ significantly by gender. In the study where the perceptions of distance education of university students were examined, it was determined that there was no statistically significant difference between male and female students (Kırali \& Alcı, 2016). In the study of Kurt and Özkan (2014), the satisfaction levels of learners for distance education did not differ significantly by gender. It has been stated that the distance education system satisfaction and satisfaction levels of women who are educated with distance education method are lower than male students (Demiray, 2013). In Kaba, Güneş, and Altıntaş's (2012) study, it was stated that the level of satisfaction of learners with e-learning environments did not show significant differences according to gender.

The satisfaction of the participants showed a significant difference according to the age group. Korkmaz, Çakır, and Tan (2015) examined the readiness and satisfaction levels of e-learning among the learners, and it was found that there were differences in factor scores between different age groups in terms of satisfaction levels. On the other hand, in the study of Kurt and Özkan (2014), the satisfaction levels of learners for distance education did not show a significant difference according to age group. The satisfaction of the participants did not differ significantly according to the type of task. When the general satisfaction dimension is examined, it can be said that the first clerks and others have more positive thoughts about the process. This may be due to the fact that the participants have a majority in the clerk and other tasks. Similarly, the satisfaction of the participants did not differ significantly according to the year of work in the profession and the number of notaries. When the general satisfaction dimension was examined, it was found that those who worked in the profession for 6 years and more and those who worked in more than 1 notary personnel had more positive thoughts about the process than the others. The satisfaction of the participants with experience in the profession for the distance education process may be high as they realize the advantages of distance education in the process. The satisfaction of the participants did not differ significantly according to the educational level. When the general satisfaction dimension was examined, it was found that primary and secondary school graduates had more positive thoughts about the process than the others. In this case, distance education materials can be said to be effective at all levels. The satisfaction of the participants did not differ significantly according to their previous experience of distance education. Similar to the finding in the study of Adnan and Boz Yaman (2017), the satisfaction of learners for e-learning did not differ significantly according to their e-learning experience. In the study of Kurt and Özkan (2014), the satisfaction levels of the 
learners for distance education did not show a significant difference compared to the experience of distance education.

The recommendations of the study are as follows:

- In this study, the opinions of the participants were not taken before the distance education process, but were taken in the process. Attitudes of the participants towards the process can be examined by applying scales before and after the distance education process. Thus, the effects of the designed distance education process on employees and the organization can be clearly shown.

- During the distance education process, a qualitative study can be conducted by obtaining open-ended questions from the participants. Thus, the participants' views about the process can be clearly revealed and innovations or improvements can be made in the process.

- The opinions of the participants can be examined according to the types of content presented (such as video, document and picture). Thus, improvements can be made by learning which type of content is preferred.

- A mixed study can be done by examining the contents created in the distance education process according to design principles.

\section{ACKNOWLEDGEMENTS}

Thank you to the Notaries Union of Turkey, Department of Education, notary, protonotary, clerk et al.

\section{REFERENCES}

Adams, A. (2004). Pedagogical underpinnings of computer-based learning. Journal of Advanced Nursing, 46(1), 5-12. https://doi.org/10.1111/j.1365-2648.2003.02960.x

Adnan, M., \& Boz Yaman, B. (2017). Profile of engineering undergraduates on readiness and satisfaction for e-learning. Turkish Journal of Computer and Mathematics Education, 8(2), 218-243. https://doi.org/10.16949/turkbilmat.280165

Alonso, F., López, G., Manrique, D., \& Viñes, J. M. (2005). An instructional model for web-based e-learning education with a blended learning process approach. British Journal of Educational Technology, 36(2), 217-235. https://doi.org/10.1111/j.1467-8535.2005.00454.x

Arbaugh, J.B., \& Fich R.B. (2002). The importance of participant interaction in online environments. Decision Support Systems, 43(3), 853-865. https://doi.org/10.1016/j.dss.2006.12.013

Baturay, M.H., \& Yükseltürk, E. (2015). The role of online education preferences on student's achievement. Turkish Online Journal of Distance Education, 16(3), 3-12. https://doi.org/10.17718/tojde.47810

Demiray, E. (2013). Distance learning and its importance in education of woman. Journal of Research in Education and Teaching, 2(2), 155-168. Retrieved from http://www.jret.org/FileUpload/ks281142/File/18._emine_demiray.pdf

Douglas, D. E., \& Van Der Vyver, G. (2004). Effectiveness of e-learning course materials for learning database management systems: An experimental investigation. Journal of Computer Information Systems, 44(4), 41-48. https://doi.org/10.1080/08874417.2004.11647594

Eom, S. B., Wen H. J., \& Ashill N., (2006). The determinants of students' perceived learning outcomes and satisfaction in university online education: an empirical investigation. Decision Sciences Journal of Innovative Education, 4(2), 215-235. https://doi.org/10.1111/j.1540-4609.2006.00114.x 
Eygü, H., \& Karaman, S. (2013). A study on the satisfaction perceptions of the distance education students. Kırıkkale University Journal of Social Sciences, 3(1), 36-59. Retrieved from https://www.researchgate.net/profile/Hakan_Eygu/publication/263968079_A_Study_On_The_Satisf action_Perceptions_Of_The_Distance_Education_Students/links/58bfc5cd92851cd83aa13c1b/AStudy-On-The-Satisfaction-Perceptions-Of-The-Distance-Education-Students.pdf

Güeçoğlu, E. (2012). Determination of satisfaction levels of people employed in institutions for distance education (Master's Dissertation), Marmara University Graduate School of Social Sciences, İstanbul.

Gülbahar, Y. (2012). Study of developing scales for assessment of the levels of readiness and satisfaction of participants in e-learning environments. Ankara University Journal of Faculty of Educational Sciences, 45(2), 119-138. https://doi.org/10.1501/Egifak_0000001256

Gürpınar, E., Zayim, N., Başarıcı, İ., Gündüz, F., Asar, M., \& Oğuz, N. (2009). E-learning and problem based learning integration in cardiology education. Anatol J Cardiol., 9(3),158-164. Retrieved from http://www.anatoljcardiol.com/jvi.aspx?pdir=anatoljcardiol\&plng=eng\&un=AJC-94475

Joo, Y. J., Lim, K. Y., \& Kim, E. K. (2011). Online university students' satisfaction and persistence: Examining perceived level of presence, usefulness and ease of use as predictors in a structural model. Computers \& Education, 57(2), 1654-1664. https://doi.org/10.1016/j.compedu.2011.02.008

Joseph, F., Hair, Jr., William, C., Black Barry J., \& Babin Rolph E., (2014). Multivariate Data Analysis, Anderson Seventh Edition. Retrieved from https://pdfs.semanticscholar.org/6885/bb9a29e8a5804a71bf5b6 e813f2f966269bc.pdf

Justice, P. (2005). Achieving Value from e-Learning.

Kaba, A. U., Güneş, A., \& Altıntaş, T. (2012). The effect of support services on learner satisfaction in e-learning. Journal of Educational Technologies Research, 3(2), Retrieved from http://www.idealonline.com.tr/IdealOnline/lookAtPublications/paperDetail.xhtml?uld=12662

Kantoğlu, B., Torkul, O., \& Altunışık, R. (2013). A Study on the Factors Affecting Student's Satisfaction in Elearning: A Model Proposition. Business \& Economics Research Journal, 4(1). Retrieved from http://web.a.ebscohost.com/ehost/pdfviewer/pdfviewer?vid=0\&sid=914c575e-47ca-47c7-a25aa6b82271f365\%40sdc-v-sessmgr01

Karataş, S., \& Üstündağ, M.T. (2008). The relationship between students' internet-based distance education satisfactions and demographical properties in Gazi University distance education program. Yüzüncü Yıl University Journal of Education, 5(2), 62-73. Retrieved from http://efdergi.yyu.edu.tr/uploads/sercin_karatas-1542114380.pdf

Kırali, F., \& AlcI, B. (2016). University student opinions regarding the perception of distance education. Journal of Istanbul Aydin University, 8(30), 55-83. Retrieved from https://dergipark.org.tr/tr/pub/iaud/issue/30078/324645

Korkmaz, Ö., Çakır R., \& Tan, S. S. (2015). Students e-learning readiness and satisfaction levels and effects on the academic achievement. Journal of Kirsehir Education Faculty, 16(3), 219-241. Retrieved from http://kefad.ahievran.edu.tr/Kefad/Archivelssues/Detail/3bfb96e8-6352-e711-80ef-00224d68272d

Kurt, N., \& Özkan, Y. (2014). Factors affecting the academical success in distance education. Journal of Hasan Ali Yücel Faculty of Education, 11(2). Retrieved from https://search.proquest.com/openview/ 582f5fca9de1bdcf36f8fe1de6ec1f77/1?pq-origsite=gscholar\&cbl=1796367

Macpherson, A., Homan, G., \& Wilkinson, K. (2005). The implementation and use of e-learning in the corporate university. Journal of Workplace Learning, 17(1), 33-48. https://doi.org/10.1108/13665620510574441 
Martin, G., Massy, J., \& Clarke, T. (2003). When absorptive capacity meets institutions and (e) learners: adopting, diffusing and exploiting e-learning in organizations. International Journal of Training and Development, 7(4), 228-244. https://doi.org/10.1046/j.1360-3736.2003.00183.x

Mwanza, D., \& Engeström, Y. (2005). Managing content in e-learning environments. British Journal of Educational Technology, 36(3), 453-463. https://doi.org/10.1111/j.1467-8535.2005.00479.x

Öztürk, A., Kara, Y., Özkeskin, E., \& Uça Güneş, E. (2017). Satisfaction of open and distance learners regarding learning management system and learning materials. Journal of Open Education Practices and Research, 3(4), 81-107. Retrieved from https://dergipark.org.tr/en/pub/auad/issue/34247/378486

Parasuraman, A., V. A. Zeithaml \& L. L. Berry. (1988). SERVQUAL: A Multiple-Item. Retrieved from https:// www.researchgate.net/profile/Valarie_Zeithaml/publication/225083802_SERVQUAL_A_multiple_Item_Scale_for_measuring_consumer_perceptions_of_service_quality/links/5429a4540cf27e39fa8 e6531/SERVQUAL-A-multiple-Item-Scale-for-measuring-consumer-perceptions-of-service-quality.pdf

Rumble, G. (2019). The planning and management of distance education. London: Routledge. https://doi.org/10.4324/9780429288661

Şahin, A. E. (2009). Assessing service quality in faculty of education via student satisfaction scale (fe-sss). Hacettepe University Journal of Education, 37, 106-122. Retrieved from http://www.efdergi.hacettepe.edu.tr/shw_artcl-495.html

Sahin, I., \& Shelley, M. (2008). Considering students' perceptions: The distance education student satisfaction model. Journal of Educational Technology \& Society, 11(3), 216-223. Retrieved from https://www.jstor.org/stable/jeductechsoci.11.3.216?seq=1\#metadata_info_tab_contents

Shea, P., Pickett, A., \& Pelz, W. (2003). A follow-up study of teaching presence in the online program. Journal of Asynchronous Learning Networks, 7(2), 61-80. Retrieved from https://www.researchgate.net/ publication/228831416_A_follow-up_investigation_of_teaching_presence_in_the_SUNY_Learning_ Network/link/02e7e53bee224063e4000000/download

Simonson, M., Zvacek, S. M., \& Smaldino, S. (2019). Teaching and Learning at a Distance: Foundations of Distance Education 7th Edition. IAP. Retrieved from https://books.google.com.tr/books?id=qh3DwAAQBAJ\&printsec=frontcover\&hl=tr\&source=gbs_ge_summary_r\&cad=0\#v=onepage\& $q \& f=f a l s e$

Sırakaya, M., Sırakaya, D. A., \& Kılıç Çakmak, E. (2015). Investigation of the level of distance education students' attitude towards online exam. Kastamonu Education Journal, 23(1), 87-104. Retrieved from https://dergipark.org.tr/tr/pub/kefdergi/issue/22600/241466

Spector, J. M., Merrill, M. D., Elen, J., \& Bishop, M. J. (2014). Handbook of research on educational communications and technology. New York, NY: Springer. https://doi.org/10.1007/978-1-4614-31855

Sun, P. C., Tsai, R. J., Finger, G., Chen, Y. Y., \& Yeh, D. (2008). What drives a successful e-Learning? An empirical investigation of the critical factors influencing learner satisfaction. Computers \& education, 50(4), 1183-1202. https://doi.org/10.1016/j.compedu.2006.11.007

Toker Gökçe, A. (2008). Küreselleşme sürecinde uzaktan eğitim. Journal of Dicle University Ziya Gökalp Faculty of Education, (11), 1-12. Retrieved from https://dergipark.org.tr/tr/pub/zgefd/issue/47957/606765

Yılmaz, H., \& Düğenci, M. (2010). Different approach in-service training: e-service training. 12th Academic Informatics Conference, 67-74. Retrieved from http://ab.org.tr/ab10/kitap/yilmaz_dugenci_AB10.pdf

Correspondence: Gizem Yildiz, Gazi University, Turkey. E-mail: gizzyildiz@gmail.com 